\title{
The Impact of Englishgame-Based Mobile Application on Students' Reading Achievement and Learning Motivation
}

\author{
Nina Sofiana \\ Universitas Islam Nahdlatul Ulama Jepara, Indonesia, ninasofiana@unisnu.ac.id \\ Husni Mubarok \\ Universitas Islam Nahdlatul Ulama Jepara, Indonesia, husni@unisnu.ac.id
}

This study is aimed at finding the impact of Englishgame-based Mobile Application (EBMA) on reading achievement and learning motivation of the students. It is an experimental research which uses test and questionnaire to gather the data. 119 samples (58 students of experimental group and 61 students of control group) are selected from eighth grade students of junior high school spread into urban and rural areas in the Jepara Municipality of Central Java Province under the Ministry of Education and Culture Indonesia. By using multivariate analysis of variance (Manova), it was found that the use of EBMA in learning could increase the students' achievement in reading. The students who used EBMA as a medium of learning had better achievement in reading than those who did not $(71.12>65.52)$. Then, students' motivation in learning differed significantly after the implementation of EBMA. It was higher since the activities engaged and motivated them to learn. Therefore, it indicates that the use of EBMA have great impact on students' reading achievement and learning motivation.

Keywords: English game, mobile application, reading, motivation

\section{INTRODUCTION}

Teaching English in junior high schools (JHS) in Indonesia focuses on increasing the students' competence to use the language in communication in various contexts, both oral and written. It is expected to be able to equip students to achieve functional literacy levels; that is to use language to meet daily needs. (Brindha, 2018) state that the main goal of language education emphasis is to build the language efficiency within stipulated durations which includes the basic literacy level of reading and writing. Therefore English learning is designed to provide experience in using English texts to understand and apply factual, conceptual, and procedural knowledge related to phenomena and events through listening, speaking, reading and writing activities. 
To achieve this goal, the teacher plays an important role in directing students' knowledge where he/she must build and shape their knowledge and character. To make students get maximum achievement in learning process and build their motivation level, the teacher should apply various teaching strategies and media. It needs to implement to meet the principles of the ELT 2013 curriculum; 1) student-centered pedagogy is of top priority; 2) interactive pedagogy involves interactions between teacher and students, between students and materials, and between students and their social environments; 3 ) integrated pedagogy assists students to explore what they need to learn and to see interconnectedness among a variety of materials through direct observations and mediated observations through the Internet; 4) exploratory and engaging learning and teaching are framed in scientific inquiry or discovery learning; and 5) a collaborative principle underpins a learning process (Widodo, 2016). The question arises then whether the teacher has applied the appropriate strategy and media or not.

Among the four skills of English, reading plays an important role because students' ability to read and understand texts efficiently is important to meet daily communication needs as well as success in academics. Learning reading could not be separated with writing as mentioned by Bharuthram \& Clarence (2015) that state in higher education, writing about something generally stems from reading about something, and the level at which one is reading determines the relevance and clarity of what one writes. In reading, students are asked to read a greater amount of texts both loudly or silently. Reading can be defined as a process of making meaning from a text that provide the students to have ability in understanding text by using their grammatical vocabulary, and prior knowledge (Richards, 2015) and a complex activities which require a range of cognitive skills to extract textual meaning so that learners could require literacy gradually (Huang \& Yang, 2015).

Since reading is a process, it needs several skills to master (Harmer, 2007a). Those skills are identifying the topic, predicting and guessing, reading for general understanding, reading for specific information, reading for detail information, and interpreting text. The cognitive skills of reading can be acquired easily through positive communication between the educator and learners (Alharbi, 2015). (Pratiwi, 2016) adds that the reading skills can be classified into six categories; identifying the structure of the text, identifying the context of the text, identifying the meaning, recognizing the reading speed, identifying the communicative function, and applying the reading strategies. It means that students' reading skill is essential to learning (Severino, Jean, Decarlo, \& Sondergeld, 2018) and necessary for language learners to acquire new information about textbook (Khansir \& Farajolahzadeh, 2015). However, students of JHS still find some problems in enriching their reading skill.

The main problems faced by students in reading are the lack of understanding the main message of the text they read and their low motivation in reading. These problems are in accordance with the statement described by Wu (2012) and Nejabati (2015) where the main issue about learning reading is comprehending the passage. This situation is made worse by many teachers who still focus on reading aloud and connecting between symbols and meanings. (Pratiwi, 2016) found that students tended to fail in acquiring the 
significant meaning of the text since they had limited vocabulary, lack of fluency, might not know about the reading strategies and the lack of media that is applied in reading instruction. Lacking in reading skills, or even having lower than normal reading abilities can result in truancy, underpaid jobs, and falling prey to the cycle of illiteracy in the next generation (Alharbi, 2015). Therefore, these problems can be overcome if the teacher applies a variety of learning media.

The use of media in learning is expected to increase students' reading achievement and their learning motivation. Motivated readers are more engaged in reading, have more positive attitude toward reading, and give more meaning to the reading process (Pečjak \& Peklaj, 2006). Motivation is needed by students when they read. Motivated students would try to understand the meaning implied in text deeply. Motivation could be defined as the extent to which you make choices about goals to pursue and effort that will be devoted to that pursuit (Brown, 2001) and it is kind of internal drive which pushes someone to do the thing in order to achieve something (Harmer, 2007b). Ausable in Brown (2001) elaborated six drives in motivation; exploration, manipulation, stimulation, knowledge, and ego enhancement. The definition makes motivation as the most important thing in teaching English as a foreign language (Ariane \& Pascale, 2012). Learning motivation can be defined as a mental strength of students that come from outside and emerge from self; it will encourage students to be motivated learner and will make them eager to learn (Zainudin, 2016). Pečjak \& Košir (2008) add that reading motivation is a multidimensional series of goal and belief that direct reading behavior and are mostly in positive relationship with each other. It can be concluded that learning motivation is critical to reading achievement.

One of the media that can be used in teaching reading is Englishgame based mobile application. The game used is under the basis of mobile assisted language learning (MALL). The common features in MALL include voice recording, listening to audio and video file, app installation, reading books, authentic content etc. In language learning, all these features enable communicative language practice (Brindha, 2018). Mobile means that it can be accessed anywhere and anytime without being limited by time and place. This shows that the game used can be used both in the online (if multiplayer are played) and offline (if a single player is used).

The use of media in learning reading is essential since the learning process involves the relationship between learning components that include students, teachers, learning media, learning materials and learning environments. This is in line with Wu \& Huang (2017) who stated that for meeting the instructional objectives of English learning and the digital game-based instructional strategy, and for promoting the introduction of mobile devices, their study provided a game-based learning environment to immerse learners in game-based learning and to improve their learning experience. This system could enable learners to achieve autonomous learning and self-planning according to the curricular objectives and needs; moreover, the teacher used instructional objectives and the learning scope to set the game content to meet curricular objectives. Heinich, Molenda and Russel in Ishak \& Dermawan (2013) distinguishes instructional methods from instructional media. The method is the learning step chosen to help students 
achieve their goals, while the media is the messenger or information between the source and recipient.

Englishgame-based mobile application (EBMA) is a kind of digital game which consists of texts, voice from native speaker, and sound. Wu \& Huang (2017) mention that digital game-based learning can effectively enhance the attention, interest, creativity, and community relationships of students and promoting learners' educative engagement and motivation (Young \& Wang, 2014). In addition, the use of game in instructional activities is an active learning strategy that encourages student engagement (Smale, 2012).

There are some studies which relates to this study. Cabral-Márquez (2011) claimed that reading activity could be predicted from reading motivation, while reading motivation could be associated from reading activity. Students who were treated by using both drill and game-based activities performed better in term of English pronunciation than the students who only participated in the drill practice (Young \& Wang, 2014). In addition, the use of online game in the form of Massively Multiplayer Online Games helped students to perform better in English and Business class teaching (Bawa, Watson, \& Watson, 2018) and motivated students to complete quiz in the game (Smale, 2012).

Based on the facts mentioned above, developing reading by utilizing the instructional media in teaching-learning process is essential. Therefore, it is necessary to use Englishgame-based mobile application as learning media in reading classes to find the significant impact on students' reading skill.

\section{Purpose of Research}

This study is aimed at 1) examining the difference in students' reading achievement after being taught by using Englishgame-based mobile application (EBMA), 2) examining the difference in students' motivation level after being taught by using (EBMA), and 3) examining the difference in students' reading achievement and motivation level between those who were taught by using EBMA and those who were not.

\section{METHOD}

The research method used in this study was a true experimental research of pretestposttest control group design analyzed quantitatively. There are two variables in this study: independent and dependent variable. The independent variable is Englishgamebased mobile application (X1) for experimental group and conventional teaching technique for control group, while the dependent variable is students' reading comprehension (Y1) and learning motivation (Y2). The population in this study was the eighth grade students of junior high school class who were spread into urban and rural areas in the Jepara Municipality of Central Java Province under the Ministry of Education and Culture Indonesia. The total population was 490. By using simple random sampling, 119 samples from eighth grade students of junior high school were obtained; 58 students in experimental group and 61 students in control group.

To get good research data, the instruments used in this study were in the form of reading test and questionnaire. The test was used to determine the students learning outcomes in 
reading. It was multiple choice tests with a total of 40 questions. It was given twice, for the pre-test and post-test. The pre-test was carried out to determine the students' initial abilities before being treated using media (Englishgame-based mobile application for experimental group and conventional teaching technique for control group), while the posttest was used to determine students' reading skill after being given treatment. Then, four-point Likert scale questionnaires consisting of 21 statements were answered by respondents to get the students' learning motivation level after being taught by using EBMA. The questionnaire used was based on the basis of motivation to learn (Slavin, 1995), learning goal (Passey, Rogers, Machell, \& McHugh, 2004), and experience and self-knowledge (Brown, 2001). To avoid the bias of the study, this study used internal validity expert judgment.

The instrument was analyzed statistically by using multivariate analysis of variance (Manova) with the help of SPSS 20 program. It was used to examine the significant difference between experimental group and control group. Manova requires the data should be in normal distribution and variance scoring should be homogeneous by using Levene's test. Based on the calculation of Box's Test of Equality of Covariance Matrices, it was found that the data both in pre-test and post-test were in normal distribution which showed the probability significance $(\mathrm{p})$ of pre-test 0,081 and post-test 0,246 were higher than $\alpha=0,05$. It means that the data of students in pre-test and posttest were normal in distribution. On the other side, the output Levene's Test of Equality of Error Variances showed that both variables are normal because the significance score was higher 0.05 at $5 \%$ significance level. Therefore, the MANOVA analysis can be continued.

Before the post-test was given, the researcher gave treatment to both groups; experimental and control group. The research design is illustrated in detail like the following:

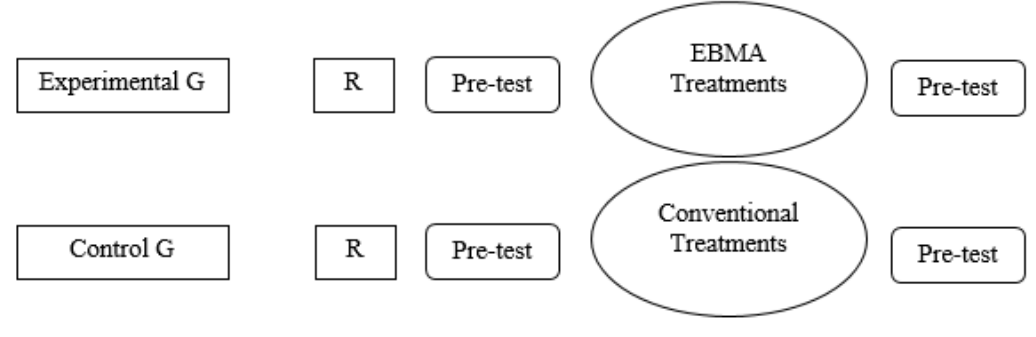

Before being treated; experimental and control groups were given a pre-test and prequestionnaire. A pre-test was conducted to obtain information about the initial conditions of the students' reading skill before treatment. The pre-questionnaire was 
used to determine the level of motivation of students before being treated in the two groups above.

The treatment was carried out for 3 times in each group. Both experimental and control groups, first, were given an explanation of the reading material and reading strategy. The material was delivered by using a handbook and displayed via power point. On this occasion, students were given the opportunity to conduct discussions in pairs related to the material. After that, students were asked to discuss questions about reading contained in the handbook in pairs. In addition to the experimental group, students were asked to use Englishgame-based mobile applications that were accessed through the Smartphone of each student. This game could be played in pairs using an internet connection. Before students logged in, they were asked to accept an invitation to play in this game. Each student had 30 seconds to answer each question that appeared in the application. Students took turns in answering questions. Students who were able to answer correctly, they got points and had the right to continue the game. On the contrary, students who answered incorrectly, they did not get points.

After the treatments, the posttest and post-questionnaire were given to find out the students' reading skill and their level of learning motivation. The results of measurements of the level of reading skill and students' motivation were compared by using Manova to determine the effect of EBMA on students' reading skill and motivation.

\section{FINDINGS AND DISCUSSION}

Before both groups (experimental and control group) were given treatments, they were pre-tested first to find students' initial level of reading achievement and their learning motivation. The result of mean score could be described like the following:

Table 1

Descriptive Statistics before Treatment

\begin{tabular}{|c|c|c|c|c|c|}
\hline Variables & Types & Group & Mean & Std. Deviation & $\mathrm{N}$ \\
\hline \multirow{6}{*}{$\begin{array}{l}\text { Reading } \\
\text { Achievement }\end{array}$} & \multirow{3}{*}{ Pre-test } & Control & 54,49 & 16,017 & 61 \\
\hline & & Experiment & 65,79 & 11,566 & 58 \\
\hline & & Total & 60,00 & 15,075 & 119 \\
\hline & \multirow{3}{*}{ Post-test } & Control & 65,52 & 15,593 & 61 \\
\hline & & Experiment & 71,12 & 11,941 & 58 \\
\hline & & Total & 68,25 & 14,157 & 119 \\
\hline \multirow{6}{*}{ Motivation } & \multirow{3}{*}{$\begin{array}{l}\text { Pre- } \\
\text { questionnaire }\end{array}$} & Control & 55,05 & 5,917 & 61 \\
\hline & & Experiment & 58,52 & 5,774 & 58 \\
\hline & & Total & 56,74 & 6,078 & 119 \\
\hline & \multirow{3}{*}{$\begin{array}{l}\text { Post- } \\
\text { questionnaire }\end{array}$} & Control & 61,34 & 3,646 & 61 \\
\hline & & Experiment & 71,17 & 3,535 & 58 \\
\hline & & Total & 66,13 & 6,094 & 119 \\
\hline
\end{tabular}

From the calculation of mean score in both groups, it was found that the students' reading pre-test average in the experimental group (65.79) was higher than the control group (54.49). Besides that, the difference in mean values was also found in pre- 
questionnaire of learning motivation where the experimental group (58.52) which was larger than the control group 55.05. Then, the mean score of reading post-test average of students in the experimental group (71.12) was higher than the control group (65.52). Furthermore, the difference in mean values was also found in post-questionnaire of learning motivation where the experimental group (71.17) which was larger than the control group (61.34).

Table 1 implies that there is an increasing in the reading achievement mean score after being given treatment by 5.33 points. The mean score of student learning motivation also increases after the treatments are carried out. The increasing is 12.65 points. This shows that students' reading achievement and learning motivation in experimental group better than the control. This preliminary conclusion must be made to prove the Manova test in Table 2.

The hypothesis test is used to examine the significance and non-significance of reading achievement and learning motivation. In this study there were two hypotheses which were examined. The first hypothesis is about reading achievement while the second hypothesis is about learning motivation. The criterion of the all hypotheses were null hypothesis was rejected if $\mathrm{p}<\alpha$ (or it can be said $\mathrm{p}<0.05$ ) and working hypothesis was rejected if $p<\alpha$ (or it can be said $p<0.05$ ). Thus the formulation of the hypothesis of this study can be elaborated like the following:

\section{First hypothesis}

Ho: There is no significant difference in reading achievement of students who are taught by using EBMA with those who are taught using conventional game.

Ha: There is a significant difference in reading achievement of students who are taught by using EBMA with those who are taught using conventional game.

Second hypothesis

Ho: There is no significant difference in learning motivation of students who are taught by using EBMA with those who are taught using conventional game.

Ha: There is a significant difference in learning motivation achievement of students who are taught by using EBMA with those who are taught using conventional game. 
Table 2

Multivariate Analysis of Variance

\begin{tabular}{lllllll}
\hline Effect & & Value & F & $\begin{array}{l}\text { Hypothesis } \\
\text { df }\end{array}$ & Error df & Sig. \\
\hline \multirow{3}{*}{ Intercept } & Pillai's Trace &, 997 & $21074,197^{\mathrm{b}}$ & 2,000 & 116,000 &, 000 \\
\cline { 2 - 7 } & Wilks' Lambda &, 003 & $21074,197^{\mathrm{b}}$ & 2,000 & 116,000 &, 000 \\
\cline { 2 - 7 } & Hotelling's Trace & 363,348 & $21074,197^{\mathrm{b}}$ & 2,000 & 116,000 &, 000 \\
\cline { 2 - 7 } & $\begin{array}{l}\text { Roy's Largest } \\
\text { Root }\end{array}$ & 363,348 & $21074,197^{\mathrm{b}}$ & 2,000 & 116,000 &, 000 \\
\hline \multirow{3}{*}{ Group } & Pillai's Trace &, 658 & $111,554^{\mathrm{b}}$ & 2,000 & 116,000 &, 000 \\
\cline { 2 - 7 } & Wilks' Lambda &, 342 & $111,554^{\mathrm{b}}$ & 2,000 & 116,000 &, 000 \\
\cline { 2 - 7 } & Hotelling's Trace & 1,923 & $111,554^{\mathrm{b}}$ & 2,000 & 116,000 &, 000 \\
\hline & $\begin{array}{l}\text { Roy's Largest } \\
\text { Root }\end{array}$ & 1,923 & $111,554^{\mathrm{b}}$ & 2,000 & 116,000 &, 000 \\
\hline
\end{tabular}

a. Design: Intercept + Teaching_Media

b. Exact statistic

c. Computed using alpha $=, 05$

Based on Table 2, it shows the Wilks' Lambda data have F-value 111.56 and Sig 0.000 $<0.05$. It means that Ho is rejected because Sig. $p<0.05$. On the other word, it can be said that the output shows the effectiveness of EBMA in affecting students' reading achievement and learning motivation after getting treatments.

Table 3

Test of Between-Subjects Effects

\begin{tabular}{|c|c|c|c|c|c|c|}
\hline Source & $\begin{array}{l}\text { Dependent } \\
\text { Variable }\end{array}$ & $\begin{array}{l}\text { Type III Sum } \\
\text { of Squares }\end{array}$ & df & Mean Square & $\mathrm{F}$ & Sig. \\
\hline \multirow{2}{*}{$\begin{array}{l}\text { Corrected } \\
\text { Model }\end{array}$} & $\begin{array}{l}\text { Reading } \\
\text { Achievement }\end{array}$ & $931,069^{a}$ & 1 & 931,069 & 4,795 &, 031 \\
\hline & Motivation & $2871,802^{b}$ & 1 & 2871,802 & 222,510 &, 000 \\
\hline \multirow[t]{2}{*}{ Intercept } & $\begin{array}{l}\text { Reading } \\
\text { Achievement }\end{array}$ & 555136,951 & 1 & 555136,951 & 2859,091 & ,000 \\
\hline & Motivation & 522097,886 & 1 & 522097,886 & 40452,700 & ,000 \\
\hline \multirow[t]{2}{*}{ Group } & $\begin{array}{l}\text { Reading } \\
\text { Achievement }\end{array}$ & 931,069 & 1 & 931,069 & 4,795 & ,031 \\
\hline & Motivation & 2871,802 & 1 & 2871,802 & 222,510 & ,000 \\
\hline \multirow[t]{2}{*}{ Error } & $\begin{array}{l}\text { Reading } \\
\text { Achievement }\end{array}$ & 22717,368 & 117 & 194,166 & & \\
\hline & Motivation & 1510,046 & 117 & 12,906 & & \\
\hline \multirow{2}{*}{ Total } & $\begin{array}{l}\text { Reading } \\
\text { Achievement }\end{array}$ & 577992,000 & 119 & & & \\
\hline & Motivation & 524860,000 & 119 & & & \\
\hline \multirow[t]{2}{*}{ Corrected Total } & $\begin{array}{l}\text { Reading } \\
\text { Achievement }\end{array}$ & 23648,437 & 118 & & & \\
\hline & Motivation & 4381,849 & 118 & & & \\
\hline \multicolumn{7}{|c|}{ a. R Squared = ,039 (Adjusted R Squared $=, 031$ ) } \\
\hline \multicolumn{7}{|c|}{ b. R Squared $=, 655$ (Adjusted R Squared $=, 652$ ) } \\
\hline \multicolumn{7}{|c|}{ c. Computed using alpha $=, 05$} \\
\hline
\end{tabular}


Table 3 shows that the F-value of reading achievement (Y1) is 4.795 and Sig. 0.000 which is lower than 0.05 at $5 \%$ significant level. Thus, Ho is rejected and $\mathrm{Ha}$ is accepted which can be inferred that there is significant difference in students' reading achievement after being taught by using EBMA. The table also shows the output of determinant coefficient (R-square) in the level of 0.39. It means that the effect of using EBMA in students' reading achievement is $3.9 \%$. It also implies the effect of other factors on students' reading achievement is $96.1 \%$.

In addition, Table 3 shows that the F-value of learning motivation (Y2) is 222.5 and Sig. 0,000 which is lower than 0.05 at $5 \%$ significant level. Thus, Ho is rejected and $\mathrm{Ha}$ is accepted which could be inferred that there is significant difference in students' learning motivation after being taught by using EBMA. In addition, the table shows the output of determinant coefficient (R-square) in the level of 0.655 . It means that the effect of using EBMA in students' reading achievement is $65.5 \%$. It also implies the effect of other factors on students' reading achievement is $34.5 \%$.

Thus, the statistical analysis carried out in this study illustrates that there is a significant impact of Englishgame-based mobile application as a learning medium in English language teaching, especially in reading. The use of EBMA can improve students' reading achievement because the game can attract students to focus on the text they read in a game. Besides that, the quiz in the game also consists of the audio from native speaker which can help students to comprehend the text. The result of this study supports the study conducted by Shimray, Keerti, \& Ramaiah (2015) who state that the change from printed reading to mobile reading maximize students to improve students' reading skill and build their habit, attitude and behavior to online/mobile activities. Likewise, Somyürek (2014) found that teaching and learning process by using construction tools offered students opportunities to deepen the understanding of various concepts with hands-on exploration and design which resulted in fun and enjoyment activities and promote their active involvement and collaboration that leads to developing multiple perspectives. Vlachopoulos \& Makri (2017) also claim that the use of game has a positive effect on students' learning goals.

In line with the study conducted by Nouthaphone (2016), Smale (2012), and Passey et al. (2004) that the use of media can enhance students' motivation. Furthermore, EBMA as a kind of digital game-based learning can affect teaching and learning process significantly (Hussain, Tan, \& Idris, 2014; Iacovides, Aczel, Scanlon, Taylor, \& Woods, 2011; La Guardia, Gentile, Dal Grande, Ottaviano, \& Allegra, 2014; Panoutsopoulos \& Sampson, 2012). The students are more motivated since their interest in learning increases. The use of EBMA in reading learning makes all students excited and enthusiastic in the learning process because they felt free to explore their ability. They enjoyed the learning process since it was more interesting and also effective. They were unconsciously involved actively in learning process. When the students were playing the game, they had a high desire to complete the activities and challenges in the game. So, it can be concluded that using EBMA in learning process engages and motivates students to learn. 


\section{CONCLUSION}

The finding shows that using Englishgame-based Mobile Application (EBMA) in reading learning classes can enhance achievement and motivation of the students in reading. It is because EBMA as a medium of learning provide an interesting teaching and learning activities. The activities in the game can motivate the students to actively involved in the learning process that lead them to the increasing of their interest and attracting their attention in learning. To sum up, it can be recommended that EBMA must be regarded as a medium to reading learning process. It can be implemented to reading classes to make it more effective and interesting. However, in implementing this game, it needs technology of Smartphone to play in which there are some schools that do not allow their students to use it in the class. Therefore, the school's policy related to this implication needs to be reviewed.

\section{ACKNOWLEDGEMENTS}

Appreciation is given to the Directorate of Research and Community Service, Directorate General of Research Improvement and Development, Ministry of Research, Technology, and Higher Education of the Republic of Indonesia, which has provided funding for this research and Institute of Research and Community Service (LPPM) UNISNU Jepara Indonesia.

\section{REFERENCES}

Alharbi, M. A. (2015). Reading strategies, learning styles and reading comprehension: A correlation study. Journal of Language Teaching and Research, 6(6), 1257-1268. https://doi.org/http://dx.doi.org/10.17507/jltr.0606.1.

Ariane, R., \& Pascale, H. (2012). The impact of age and gender on the learners' motivation and attitudes towards French in secondary education in Flanders. Proceedings of INTED 2012 Conference, (March), 159-165. Valencia, Spain.

Bawa, P., Watson, S. L., \& Watson, W. (2018). Gaming the performance: Massively multiplayer online games and performance outcomes in english and business courses. Journal of Virtual Worlds Research, 11(2), 1-22. https://doi.org/10.4101/jvwr.v11i2.7291.

Bharuthram, S., \& Clarence, S. (2015). Teaching academic reading as a disciplinary knowledge practice in a higher education. South African Journal of Higher Education, 29(2), 42-55. https://doi.org/https://doi.org/10.20853/29-2-481.

Brindha, R. (2018). Virtual teaching of english language in India. Language in India, 18(1), 148-153.

Brown, D. H. (2001). Teaching by principles: An interactive approach to language pedagogy. New York: Pearson Education Limited.

Cabral-Márquez, C. (2011). The effects of setting reading goals on reading motivation, reading achievement, and reading activity. Northen Illinois University. 
Harmer, J. (2007a). How to teach english. Essex: Pearson Education Limited.

Harmer, J. (2007b). The practice of english language teaching. London: Pearson Education International.

Huang, C. T., \& Yang, S. C. (2015). Effects of online reciprocal teaching on reading strategies, comprehension, self-efficacy, and motivation. Journal of Educational Computing Research, 52(3), 381-407. https://doi.org/10.1177/0735633115571924.

Hussain, S. Y. S., Tan, W. H., \& Idris, M. Z. (2014). Digital game-based learning for remedial mathematics students: A new teaching and learning approach in Malaysia. International Journal of Multimedia and Ubiquitous Engineering, 9(11), 325-338. https://doi.org/10.14257/ijmue.2014.9.11.32.

Iacovides, I., Aczel, J., Scanlon, E., Taylor, J., \& Woods, W. (2011). Motivation, engagement and learning through digital games. International Journal of Virtual and Personal Learning Environments, 2(2), 1-16. https://doi.org/10.4018/jvple.2011040101.

Ishak, A., \& Dermawan, D. (2013). Teknologi pembelajaran. Bandung: Rosda.

Khansir, A. A., \& Farajolahzadeh, S. (2015). The effect of GI and CIRT as the cooperative techniques on learners reading comprehension at intemediate level of Iranian efl classrooms. Modern Journal of Language Teaching Methods (MJLTM), 4(5), 477-487.

La Guardia, D., Gentile, M., Dal Grande, V., Ottaviano, S., \& Allegra, M. (2014). A game based learning model for entrepreneurship education. Procedia - Social and Behavioral Sciences, 141, 195-199. https://doi.org/10.1016/j.sbspro.2014.05.034.

Nejabati, N. (2015). The effects of teaching self-regulated learning strategies on efl students' reading comprehension. Journal of Language Teaching and Research, 6(6), 1343-1348. https://doi.org/10.17507/jltr.0606.23.

Nouthaphone, T. (2016). The effectiveness of using films in the teaching of listening to improve the students leaning achievement and to enhance the students learning motivation. Universitas Negeri Yogyakarta.

Panoutsopoulos, H., \& Sampson, D. G. (2012). A study on exploiting commercial digital games into school context. Educational Technology and Society, 15(1), 15-27.

Passey, D., Rogers, C., Machell, J., \& McHugh, G. (2004). The motivational effect of ICT on pupils. Lancester: The University of Lancester.

Pečjak, S., \& Košir, K. (2008). Reading motivation and reading efficiency in third and seventh grade pupils in relation to teachers' activities in the classroom. Studia Psychologica, 50(2), 147-168.

Pečjak, S., \& Peklaj, C. (2006). Dimensions of reading motivation and reading achievement in 3RD and 7th grade students. Studia Psychologica, 48(1), 11-30. 
Pratiwi, E. B. (2016). Developing multimedia for reading instruction for the ninth grade students at SMPN 1 Kalasan Sleman DIY. Universitas Negeri Yogyakarta.

Richards, J. C. (2015). Key issues in language teaching. Cambridge: Cambridge University Press.

Severino, L., Jean, M., Decarlo, T., \& Sondergeld, T. (2018). A validation study of a middle grades reading comprehension assessment. RMLE Online, 41(10), 1-16. https://doi.org/10.1080/19404476.2018.1528200.

Shimray, S. R., Keerti, C., \& Ramaiah, C. K. (2015). An overview of mobile reading habits. DESIDOC Journal of Library and Information Technology, 35(5), 364-375. https://doi.org/10.14429/djlit.35.5.8901.

Slavin, R. E. (1995). Cooperative learning: Theory, research, and practice. Massachusetts: Allyn and Bacon.

Smale, M. A. (2012). Get in the game: Developing an information literacy classroom game. Journal of Library Innovation, 3(1), 126-147.

Somyürek, S. (2014). An effective educational tool: Construction kits for fun and meaningful learning. International Journal of Technology and Design Education, 25(1), 25-41. https://doi.org/10.1007/s10798-014-9272-1.

Vlachopoulos, D., \& Makri, A. (2017). The effect of games and simulations on higher education: a systematic literature review. International Journal of Educational Technology in Higher Education, 14(1), 1-33. https://doi.org/10.1186/s41239-0170062-1.

Widodo, H. P. (2016). Language policy in practice: Reframing the english language curriculum. English Language Education Policy in Asia, 1(11), 127-151. https://doi.org/10.1007/978-3-319-22464-0_6.

$\mathrm{Wu}$, J. (2012). The influence of extensive reading on junior high school students' reading motivation and reading performance in Taiwan. Colorado State University.

Wu, T.-T., \& Huang, Y.-M. (2017). A mobile game-based english vocabulary practice system based on portfolio analysis. Educational Technology and Society, 20(2), 265277.

Young, S. S.-C., \& Wang, Y.-H. (2014). The game embedded CALL system to facilitate english vocabulary acquisition and pronunciation. Educational Technology and Society, 17(3), 239-251.

Zainudin, M. (2016). The influence of using hypoteaching method in improving students' motivation and reading achievement in class XI students at MAN Unggul Tenggarong. Universitas Negeri Yogyakarta. 